Nama : Moch. Yahya Apriansyach

Semester/Kelas : 1/MDB

Matkul : Filsafat Ilmu

Agama dan Bayang-Bayang Etis Syaikh Yusuf Al-Makkassari

$\mathrm{BAB} 1$

PENDAHULUAN

Buku ini merupakan hasil penelitian yang dilatarbelakangi oleh kerisauan penulis terhadap krisis keindonesiaan pasca reformasi, yang berakibat pada rapuhnya kondisi sosial, ekonomi, dan politik, serta krisis moralitas yang melanda sebagian besar masyarakat Indonesia. Sikap dan perilaku yang menyimpang bisa dijumpai dalam kehidupan bernegara. Tata hukum dan tata negara disinyalir cenderung berpihak pada kepentingan penguasa. Tampaknya, sistem demokrasi yang ada hanya dinikmati oleh penguasa. Dalam konteks ini, korupsi, kolusi, nepotisme, pelanggaran hukum, dan pelecehan kemanusiaan oleh penguasa didesain dengan sistem dan mekanisme yang samar di mata publik. Padahal, Indonesia diklaim memiliki koridor hukum dan landasan etika (agama) yang jelas. Di sisi lain, Indonesia dikenal sebagai negara dengan penganut agama (Islam) terbesar, sehingga perilaku masyarakatnya dinilai sebagai representasi ajaran agama yang dianutnya. Kenyataannya, hukum dan peraturan ternyata tidak menjamin terciptanya perilaku etis dalam kehidupan berbangsa- bernegara. Banyaknya aturan tidak mengurangi pelanggaran yang terjadi. Secara tekstual dan normatif, aturan dan perundang-undangan serta agama yang memuat ajaran tentang etika, menolak sikap dan perilaku tidak etis, sehingga di dalamnya termuat sanksi dan ancaman terhadap sikap dan perilaku tidak etis. Tampaknya realitas kehidupan berbangsa-bernegara tidak menghargai anjuran-anjuran etika yang ada.

Bangsa Indonesia telah merumuskan etika yang mengatur hubungan manusia dengan Tuhan dan hubungan manusia dengan manusia dalam falsafah negara, yakni Pancasila. Pancasila sarat dengan nilai-nilai luhur dan tidak bertentangan dengan nilai-nilai agama yang ada.

Sistem demokrasi di era globalisasi telah menimbulkan perubahan yang mempengaruhi nilainilai etika yang berlaku di masyarakat. Perubahan yang terjadi juga mempengaruhi perkembangan kebudayaan, yang seringkali membongkar etika yang dianut masyarakat. Alam kebebasan yang dibungkus sistem demokrasi, menurut filosof Yunani kuno, Plato, tidak menjamin masa depan manusia yang beradab. Sistem demokrasi memberikan kebebasan berlebih kepada setiap orang untuk mengejar kepentingannya sendiri-sendiri. Standar kepantasan sosial turut berubah. Apa yang sebelumnya dianggap tidak pantas secara sosial, sekarang dianggap pantas karena banyak masyarakat yang menerimanya.

Sikap dan perilaku saling mengancam yang dilakukan oleh negara-negara yang terlibat perang, merupakan pelanggaran etika, dari penghilangan nyawa orang tidak bersalah, perampasan hakhak masyarakat, baik moril maupun materil. Levinas menyatakan bahwa, kebangkrutan etika ditandai dengan pembantaian manusia yang tidak berdosa.

Hal penting lainnya adalah munculnya kekerasan atas nama agama yang oleh sebagian kalangan disebabkan oleh sikap putus asa dan kekalahan atas penindasan yang dilakukan oleh pihak yang kuat. Kekerasan atas nama agama di Indonesia, dapat dijumpai dalam berbagai 
kasus, misalnya penyerbuan oleh massa anti Ahmadiyah, gerakan Front Pembela Islam (FPI), pemboikotan aliran-aliran sempalan, aksi-aksi untuk solidaritas Palestina, aksi-aksi anti-Barat, Yahudi, dan Amerika atas dasar sikap dan kebijakan negara-negara tersebut, serta kasus kecurigaan antara kelompok-kelompok penganut agama. Simbol agama tampil dalam wajah demonstrasi massa yang brutal dan tanpa sasaran yang logis, menyebabkan posisi dan kedudukan agama dihubung-hubungkan dengan logika bahwa agama berada di balik tindakantindakan tersebut, dan karenanya agama menjadi sistem yang lumpuh, bahkan mungkin hampir mati secara kultural (the end of culture).

Kontradiksi antara ajaran yang baik/benar di dalam agama dengan realitas kehidupan masyarakat, akhirnya memunculkan pertanyaan yang berkaitan dengan sejarah: bagaimana agama dikembangkan di dalam masyarakat? Keberhasilan ajaran-ajaran agama untuk menegakkan etika, dalam sejarahnya, tidak dapat dipungkiri. Akan tetapi, faktor-faktor kegagalannya juga perlu dicermati, terutama pada saat ini. Tampaknya agama belum memperlihatkan caranya dalam mengatasi krisis tersebut. Yang terjadi justru banyak pertentangan yang disertai dengan klaim kebenaran (truth claim) oleh kelompok-kelompok agama sendiri, sehingga mencederai ajaran agama yang secara historis dikembangkan melalui misi etis.

Etika religius menjadi tawaran untuk membebaskan manusia dari segala bentuk keterbelakangan di satu sisi, dan mengembangkan struktur sosial masyarakat untuk menciptakan keadilan dan kebajikan, di sisi lain. Selain itu, beberapa macam etika yang perlu mendapatkan perhatian terkait dengan kehidupan beragama dan bermasyarakat adalah etika sosial, etika profesi hukum, etika lingkungan, etika bisnis, etika kebidanan dan hukum kesehatan, etika customer service, etika bisnis dalam Islam, dan etika politik dan kekuasaan. Contoh-contoh etika tersebut menunjukkan bahwa dimensi etika mencakup seluruh aspek kehidupan.

Kehadiran etika religius sangat penting karena adanya proses partikularisasi nilai-nilai keagamaan dalam zaman yang terus berubah. Secara umum, semua agama, khususnya Islam menekankan pentingnya etika religius dalam kehidupan sehari-hari.17 Dalam literatur-literatur etika dasar, ada empat alasan tentang pentingnya etika religius. Pertama, masyarakat yang semakin pluralistik, termasuk aspek moral. Banyak ajaran moral saling berhadapan dan seringkali bertentangan, karena adanya truth claim. Kedua, masa transformasi di bawah hantaman gelombang modernisasi. Transformasi di semua bidang menantang nilai-nilai budaya, sehingga etika religius diperlukan agar manusia tidak kehilangan orientasi. Ketiga, proses perubahan sosial, budaya, dan moral tidak jarang dimanfaatkan oleh pihak-pihak tertentu untuk memancing di air keruh. Keempat, bagi kalangan agamawan, etika religius berfungsi untuk menemukan dasar kekokohan iman.

Ajaran-ajaran etika religius digali dari berbagai sumber, antara lain kitab suci, tradisi, ajaran atau pemikiran tokoh. Kajian ini membahas pemikiran Syaikh Yusuf al-Makassary, salah satu tokoh besar dalam sejarah Islam Indonesia. Jejaknya meliputi Sulawesi Selatan, Jawa Barat, hingga Arabia, Sri Lanka, dan Afrika Selatan. Dia adalah tokoh historis yang juga dikenal sebagai da'i, ulama, ahli tarekat, dan sufi besar yang telah mencapai puncak pendakian spiritual tertinggi dalam suluk-nya. Syaikh Yusuf juga tampil dalam peran sosial-politik, dengan menjadi mufti Kerajaan Islam Banten, dan pejuang dengan patriotisme besar melawan penjajah di Nusantara. 


\section{BAB 2}

\section{BIOGRAFI SYAIKH dan KARYA-KARYANYA}

Sejarah Syaikh Yusuf tidak terlepas dari sejarah suku Bugis-Makassar Sulawesi Selatan. Di antara sumber-sumber penelitian tentang kehidupan suku Bugis-Makassar adalah pertama, Lontara atau Lontarak, yakni kitab bacaan yang merupakan rekaman masa lalu Sulawesi Selatan. Kedua, La Galigo atau I La Galigo, yakni karya sastra Bugis yang disebut-sebut sebagai karya sastra terbesar tahun 1860 oleh bangsawan Bugis dari Tanate bernama Collipujie Arung Pancana Toa Datu Tanate. Ketiga, arsip-arsip atau naskah yang ditulis oleh sarjana asing atau sebagai arsip-arsip kolonial yang walaupun masih menimbulkan banyak polemik. Istilah Lontara atau dalam bahasa Makassar Lontarak merujuk pada beberapa pengertian, yaitu: abjad atau huruf, cerita atau bacaan, sejenis pohon dan lain-lain yang semuanya menjadi lambang identitas suku Bugis, Makassar, termasuk Mandar. Sedangkan La Galigo merupakan naskah kuno yang menceritakan keadaan atau sejarah Sulawesi Selatan sebelum masuknya Islam.

Latar belakang budaya atau masyarakat pada waktu Syaikh Yusuf dilahirkan dan dibesarkan pada abad XVI bercirikan keterbukaan terhadap pengaruh luar yang kian besar. Sejak awal sejarah, orang-orang Sulawesi Selatan telah mengenal suatu sistem kepercayaaan. Nenek moyang orang Sulawesi Selatan telah mengenal nama-nama dewa, dan beberapa jenis upacara persembahan telah dilakukan. Inti kepercayaan tersebut adalah konsep-konsep tentang dewa tertinggi yang di sebut To Palaenroe atau sang pencipta Dato Palanro, sang pengatur Aji Patoto, yang dipertuan La Puange, yang mengkaruniakan Rahmat dan menghukum yang bersalah. Konsep dewa tertinggi ini adalah sisa-sisa kepercayaan lama orang Bugis pra-Islam yang secara umum disebut Attoriyolong yang secara harfiah berarti tata cara leluhur. Di Kajang disebut Patentung, yang berarti penuntun yang dipimpin oleh seorang yang bergelar Ammatowa yang berarti ayah tertua. Kepercaaan tersebut lama-kelamaan kehabisan pengikut dan lambat laun mungkin akan dilupakan.

Pada awal peradabannya, masyarakat Sulawesi Selatan sangat dipengaruhi oleh mitos, baik yang berwujud tradisi lisan maupun tulis. Misalnya mitos tentang Simpuruh Siang di Luwu, Sinegiri di Bone, Petta Sekkangnili di Soppeng, Puteri Tamalatte di Gowa yang semuanya merupakan To Manurung yang membentuk corak kebudayaan orang Bugis dan Makassar di Sulawesi Selatan. Sedangkan mitos dalam Surek Galigo (sure' galigo) menceritakan tentang awal mula dihuninya negeri Bugis yaitu ketika Batara Guru dari dunia atas Botinglangi bertemu dengan We Nyili'timo dari dunia bawah.

\section{A. dan Latar Belakang Syaikh Yusuf Al-Makkasari \\ 1. Kelahiran}

Yusuf (nama kecil Syaikh Yusuf) lahir di Makassar pada tahun 1626 M. Lontarak Syaikh Yusuf21 menceritakan bahwa Yusuf lahir di istana Tallo pada 3 Juli 1626 M/8 Syawal 1036 $\mathrm{H}$, dari puteri Gallarang Moncongloe di bawah pengawasan Raja Gowa. Menurut Da Costa dan Davis, 22 orang tua Syaikh Yusuf termasuk kaum bangsawan. Ibunya memiliki hubungan darah dengan Raja-raja Gowa, sedangkan ayahnya masih kerabat Sultan Alauddin, salah satu 
penguasa di Sulawesi Selatan pada saat itu.23 Gelar "syaikh" diperoleh dari seorang mursyid tarekat yang membimbingnya, sesuai dengan tradisi ahli tasawuf.

Syaikh Yusuf adalah tokoh tasawuf dari Makassar yang berpengaruh dan berperan dalam pengembangan dakwah Islam, sehingga namanya disebut juga Syaikh Yusuf Taj al-Khalwaty al-Makassary. Berdasarkan cerita rakyat, pada awal perkembangan Islam di Sulawesi Selatan, orang-orang Makassar, termasuk anak-anak raja meninggalkan negerinya untuk mempelajari tasawuf Islam dan memusatkan perhatiannya pada ilmu kebatinan, kepada seorang guru yang dikenal dengan nama Syaikh Abdul Jabbar Khatib Bungsu di Tiro. Tidak heran bila banyak yang kemudian menjadi sufi dan wali yang memiliki berbagai macam kekeramatan

Menurut pihak bangsawan Gowa, Syaikh Yusuf adalah putra Sultan Alauddin dari istrinya yang bernama Gallarang Moncong Loe. Sultan Alaudin kemudian menceraikan sang istri, dan anaknya diambil alih dan diasuh oleh Sultan Alauddin di istana. Permaisuri sendiri tidak tahu akan hal itu karena perkawinan Sultan Alauddin dengan puteri Gallarang Moncongloe itu dirahasiakan. Setelah diceraikan, janda Sultan Alauddin itu menikah dengan seorang Arab bernama Khidir. Syaikh Yusuf kemudian dididik dan dibesarkan di istana Raja Gowa dengan pengetahuan Islam dan budaya masyarakat.

\section{Pendidikan}

Sejak kecil Syaikh Yusuf hidup di lingkungan yang agamis, dan kecenderungannya pada bidang keruhanian atau spiritualitas Islam. Puang Rama menulis, pada usia 3-4 tahun, Syaikh Yusuf mulai mempelajari huruf al-Qur'an hingga tamat, dan menyempurnakan tajwid dan qira'at dengan fasih, kepada seorang guru yang bernama Daeng Ri Tasammang. Pada usia 8-9 tahun, ia melanjutkan pelajaran ilmu agama Islam kepada seorang ulama besar, mufti Haramayn Makah dan Madinah yang bernama as-Syaikh Sayyid Baa Alwi Assegaf bin Abdullah al-Allaamatuttahir Assegaf di Bontoala Makassar. Menginjak usia 16-17 tahun, Syaikh Yusuf berkunjung ke Cikowang Takalar untuk belajar ilmu tasawuf kepada ulama besar yang bernama as-Syaikh Syayyid Jalaluddin al-Aidid dari Hadramaut lewat Aceh pada tahun 1645 M. Peran kedua gurunya di Bontoala dan Cikowang inilah yang mendorong Yusuf berangkat ke Makah.

Selain belajar di Gowa dan Aceh, Syaikh Yusuf juga pernah belajar di Yaman, Hijaz atau Makah dan Madinah, Syam, Damaskus. Setelah tiba di Makah, ia disambut baik oleh mufti dan seorang ulama besar yang memegang jabatan sebagai Imam madzhab

Syafi'i. Syaikh Yusuf kemudian dinikahkan dengan salah seorang putri Imam Syafi'i. Pernikahannya ini menyebabkan namanya tersebar dan memiliki pengaruh di Jazirah Arab.33 Selain itu, dia juga belajar di perguruan tarekat sufi di negeri-negeri Jazirah Arab, sehingga banyak memperoleh ijazah beserta silsilahnya.

\section{Kepribadian}

Berbagai literatur menggambarkan pribadi Syaikh Yusuf yang begitu agung. Di Makassar sosoknya dikenal sebagai pribadi yang impresif. Meskipun lahir dari keluarga berada dan di dalam lingkungan istana, syaikh Yusuf senantiasa tampil sebagai orang biasa. Keinginan 
syaikh Yusuf untuk belajar patut dijadikan teladan. Meskipun derajat ilmunya sudah tinggi, Syaikh Yusuf tidak berhenti menuntut ilmu. Jika terjadi penyimpangan, Syaikh Yusuf tidak segan-segan untuk menyampaikan pandangan atau kritiknya, meskipun, misalnya, di lingkungan istana, tempat ia dibesarkan. Syaikh Yusuf langsung menemui raja dan berdialog dengan tujuan untuk mengingatkan raja. Jika raja tidak mengikuti pendapatnya, Syaikh Yusuf meminta izin untuk hijrah dengan alasan untuk memperdalam ilmu.

Syaikh Yusuf tidak mengenal lelah menuntut ilmu. Di manapun, Syaikh Yusuf mengajarkan kehidupan yang seimbang antara kebutuhan jasmani dan rohani, dahaga intelektual dan biologis secara halal dan benar. Meskipun memiliki derajat tersendiri dan menjadi sufi andal, Syaikh Yusuf tetap rendah hati.

Ketokohan dan kepribadian Syaikh Yusuf dapat dikategorikan ke dalam empat hal: seorang sufi atau ulama; seorang intelektual atau teknokrat; seorang patriot; dan seorang mubalig.

B. Karya-Karya Syaikh Yusuf Al-Makassary

Karya-karya Syaikh Yusuf umumnya didominasi oleh dimensi tasawuf. Hal ini tidak lepas dari keterlibatan Syaikh Yusuf sendiri dalam berbagai tarekat. Dalam konteks buku ini, penulisan atau pembicaraan tentang etika Syaikh Yusuf menjadi bagian yang tidak terpisahkan dari ajaran-ajaran tasawufnya. Tasawuf menurut Syaikh Yusuf55 bertujuan untuk bertemu dengan Tuhan (Allah), melalui syarat kesucian hati (qalbu).

Adapun naskah atau karya-karya Syaikh Yusuf adalah sebagai berikut:

1. Al-Barakat al-Sailaniyyah Minal Futuhat al-Rabbaniyyah

Naskah ini berisi ajaran-ajaran etika dalam berdzikir kepada Allah, tujuan dan makna zikir, macam-macam zikir, cara-cara berdzikir.

\section{Bidayatul Mubtadi}

Naskah ini menjelaskan tentang prinsip-prinsip kepercayaan (keimanan) dalam Islam, utamanya tentang keimanan kepada Allah Swt., kitab-kitab-Nya, malaikat-malaikat-Nya, nabinabi-Nya, dan qada' dan qadlar. Naskah ini juga menekankan pentingnya kepercayaan atau keimanan bagi seorang muslim sebelum mendalami ajaran-ajaran Islam.

\section{Al-Fawaih al-Yusufiyyah fi Bayan Tahqiq al-Sufiyyah}

Naskah ini menjelaskan hakikat sufi, yaitu seseorang yang telah mencapai pengetahuan mendalam tentang Allah, dengan melaksanakan syari'at secara lahir dan batin. Selain itu, naskah ini juga membicarakan tentang syarat-syarat seseorang dapat mencapai derajat kewalian, yaitu dengan membersihkan hati dari segala penyakit hati dan cinta dunia.

\section{Hasyiah fi Kitab al-Anbah fi I'rabi La ilaaha illallah}

Menjelaskan makna kalimat tauhid La ilaaha illa Allah. Menurut orang-orang yang tidak meyakini keesaan Tuhan (kafir), terdapat benda-benda lain yang dapat digunakan untuk mendekatkan diri kepada Tuhan yang paling tinggi. Padahal, hanya Allah-lah yang dapat memberi manfaat dan mudarat.

5. Kifiyat al-Munji wal itsbat bi al-Hadis al-Qudsi 
Menerangkan tentang dzikir dan etika dalam berdzikir, penjelasan tentang manfaat-manfaat dan sebab-sebab penting-nya berdzikir kepada Allah.

\section{Matalib Salikin}

Membicarakan tiga hal penting, yaitu tauhid, makrifat, dan ibadah. Untuk memudahkan para pembaca dan muridnya, Syaikh Yusuf memberikan perumpamaan tentang ketiga hal tersebut sebagai sebuah pohon. Ketiganya merupakan satu kesatuan yang integratif dalam menuju Tuhan. Syaikh Yusuf menganalogikan tauhid sama dengan pohon, makrifat seperti dahan dan daunnya, serta ibadah seperti buahnya. Bagi siapa saja yang ingin memahami hakikat ketuhanan dan menjadi muslim yang sempurna, ketiga hal tersebut harus dipahami dengan baik dan benar. Seseorang dapat menuju Tuhan dengan melaksanakan seluruh perintah dan menjauhi larangan-Nya berlandaskan ilmu tauhid. Dalam kitab Matalib Salikin, Syaikh Yusuf menekankan arti pentingnya memahami tauhid agar tidak jatuh dalam kemusyrikan.

7. Al Nafhah al Saylaniyah

Menurut Tudjimah, naskah ini merupakan ringkasan dari tulisan-tulisan Syaikh Yusuf yang membahas tentang kondisi seseorang saat menuju Allah, seperti fana fillah atau baqabillah, yaitu tentang keadaan leburnya jiwa seorang salik dalam prosesnya mencapai makrifat kepada Tuhan. (Tudjimah, 1990: 72; Yusuf, naskah Arab, Perpustakaan Nasional RI).

\section{Qurratul Ain}

Penjelasan tentang dzikir dan tafakur. Mengajarkan tentang bagaimana seorang muslim dalam usahanya mendekatkan diri kepada Allah harus melakukan dzikir dan tafakur.

\section{Sirrul Asrar}

Menjelaskan tentang hakikat makrifat kepada Allah. Yaitu, hakikat mengenal Allah, mulai dari mengenal sifat-sifat dan kebesaran-Nya. Selain itu, juga menjelaskan rahasia pentingnya berdzikir kepada Allah, baik melalui lisan maupun gerak dan hati.

\section{Surah}

Menjelaskan tentang tiga hal penting: eksistensi Allah, alam, dan manusia, masing-masing dengan kedudukannya. Syaikh Yusuf menekankan bahwa Allah itu berdiri sendiri, sedangkan ruh berdiri dengan Allah. Badan berdiri dengan ruh, lahir berdiri dengan batin, sebagaimana alam berdiri dengan Allah dan bukan karena tempat dan waktu. Allah sebagai poros sentral seluruh jagad raya adalah pencipta segala sesuatu (Tudjimah, 1990: 82; Yusuf, naskah Arab, bundel A. 101).

\section{Taj al-Asrar fi Tahqiq Masyarib al-Arifin}

Membahas tentang makrifat, yaitu tentang hubungan antara hamba dan Tuhan serta perkataanperkataan hamba yang telah mencapai makrifat dalam berhubungan dengan Tuhan Allah.

\section{Zubdat al-Asrar fi Tahqiq ba'dha Masyarib al-Akhyar}

Tentang etika suluk yang selayaknya dilakukan oleh para salik (hamba yang menuju Tuhan). Yaitu, bagaimana etika seorangsalik dalam beribadah, berdzikir, dan berpikir tentang Tuhan dan tujuan hidupnya di dunia dan akhirat. 


\section{Fathu Kayfiyyat al Dzikr}

Menekankan pentingnya dzikir La ilaaha illa Allah dan maknanya. Selain itu, Syaikh Yusuf juga membahas etika yang selayaknya dilakukan oleh seorang salik ketika berdzikir melafalkan kalimat syahadat, baik etika lahiriah maupun batiniah.

\section{Daf'ul Bala}

Adalah risalah tasawuf yang membahas tentang sifat-sifat Allah, sifat-sifat dan hakikat waliyullah, serta etika dalam berzikir.

15. Hadzihi fawaid azhimat al-dzikr La ilaaha illalah

Membahas tentang faedah-faedah mengucapkan dzikir La ilaaha illa Allah, dzikir hu, hu, hu, serta dzikir Allah, Allah.

16. Muqaddimah al-Fawaid allati ma labudda minal aqaid

Risalah ini membicarakan tentang hakikat iman dan syarat-syarat seseorang dapat menjadi waliyullah.

\section{Tahsilul Inayat wa al-Hidayat}

Risalah ini berisi pelajaran tentang hubungan para waliyullah dengan sifat-sifat Allah serta juga pelajaran tentang dzikir dalam upaya mendekatkan diri kepada Allah.

18. Ghayatul ikhtisar wa Nihayat al-intizar

Tulisan ini berisi tentang pengertian dan hukum-hukum al-a'yan al-thabitah, (segala sesuatu yang tetap), ibaratnya, dan maknanya.

19. Tuhfatul Amr fi Fadlilat al-dzikr

Risalah ini berisi ajaran tentang sifat-sifat Allah serta kemuliaan zikir La ilaaha illa Allah.

20. Tuhfat al-Abhar li Ahlil Asrar

Risalah ini berisi ajaran tentang tauhid, akhlak (etika), kiblat menurut pemahaman kaum sufi dan juga para waliyullah.

21. Al-Washiyyat al-Munjiyyat an-mudahar al-Hijaib

Risalah ini berisi ajaran tentang wasiat yang menerangkan kesempurnaan sifat-sifat Allah, yang suci dari segala kelemahan dan kekurangan. Selain itu, juga berisi wasiat-wasiat tentang pentingnya memperbanyak dzikir kepada Allah.

Saat itu Syaikh Yusuf hanya menulis risalah-risalah pendek. Hal ini karena beberapa hal, pertama, situasi politik yang membuat Syaikh Yusuf disibukkan dengan perjuangan dan pembinaan umat. Hal serupa juga terjadi pada seorang ulama Betawi yang terkenal, yaitu Kiai Syafi'i Hadzami. Kedua, aspek pengulangan sebagai metode yang mungkin dimaksudkan agar tetap melekat sehingga pesan-pesan dalam pengajaran tidak mudah terlupakan. Pengulangan juga merupakan suatu tradisi dalam sistem hafalan. Ketiga, kebiasaan atau ciri ulama sufi yang memiliki kedalaman ilmu pengetahuan seringkali tidak mendokumentasikan karyanya secara tertulis; hanya dilihat pada saat menjawab pertanyaan-pertanyaan yang ditujukan kepadanya. 
$\mathrm{BAB} 3$

\section{BASIS PEMIKIRAN ETIKA}

\section{RELIGIUS SYAIKH YUSUF}

Pada prinsipnya, karya-karya Syaikh Yusuf menekankan pada pentingnya penguasaan syar'iat, baik secara lahir maupun batin. Hampir semua karyanya yang berhasila ditemukan berkaitan dengan masalah tasawuf dan tarekat, selain masalah keislaman lainnya.

Untuk memahami landasan etika religius Syaikh Yusuf, kita perlu mengetahui terlebih dahulu beberapa konsep kunci dalam karya-karyanya. Konsep-konsep tersebut merupakan empat tingkatan dalam praktik sufisme, yaitu syari'at, tarekat, hakikat, dan makrifat.

A. Syariat

Syari'at adalah jalan terang dan jalan baik yang dapat diikuti oleh setiap orang. Syaikh Yusuf memberikan makna filosofis dalam karyanya, al-Nafhat al-Sailaniyya, bahwa syari'at adalah kata-kata atau pemahaman Islam (teaching of Islam.) Makna yang paling mendasar, syari'at adalah etika dan moralitas yang bisa ditemukan pada semua agama. Syari'at menyediakan tuntutan untuk hidup dengan sebaik-baiknya di dunia ini. Tanpa mengikuti syari'at, ibarat membangun rumah tanpa fondasi. Karena kehidupan dibangun di atas prinsip-prinsip moral dan etika, maka mistisisme tidak dapat bberkembang

Syari'at adalah tahapan di mana gagasan tentang Tuhan berkesan pada manusia sebagai wibawa yang merujuk pada rasa tunduk kepada Tuhan. Ini adalah laku kesadaran, bukan wujud ketakutan sebagaimana yang sering diperkirakan orang. Misalnya, seseorang berdoa, menyembah, dan memikirkan Tuhan, serta memilih untuk membangun hubungan dengan-Nya, sehingga di saat tidak berdaya maka ia akan kembali kepada Tuhan. Syari'at adalah tahapan ketika seseorang berpikir tentang sesuatu yang menyenangkan atau mengecewakan. Diawali dengan mempelajari agama dari orang tuanya, bahwa perbuatan baik akan membahagiakan dan kesombongan akan mengecewakan.

B. Tarekat

Dalam al-Nafhat al-Sailaniyya, Syaikh Yusuf memaknai tarekat sebagai hal atau kondisi diri untuk menghampiri Allah (the way to God). Tarekat mengacu pada praktik atau laku sufisme. Jalan ini tidak selalu terang seperti halnya jalan raya, dan juga bukan jalan yang bisa dilihat 
dengan kasat mata. Dalam konteks ini, syari'at hanya mengacu pada aspek lahiriah, sedangkan tarekat pada laku batiniah/sufisme. Pemandu yang dibutuhkan adalah seorang syaikh atau guru sufi yang dapat menunjukkan jalan untuk mencapai Tuhan. Syari'at membuat kehidupan seharihari menjadi menarik, sedangkan hakikat dirancang untuk membentuk kehidupan batin menjadi bersih dan murni. Dalam hal ini, syari'at dan hakikat bersifat saling melengkapi.

Sebagai institusi, tarekat muncul pada abad IX. Pada masa itu kaum sufi terkenal zuhud, dan mereka berkumpul dalam suatu ikatan persaudaraan yang tidak terorganisir, tetapi mempunyai pertemuan rutin yang biasa disebut ribat. Kemunculan tarekat merupakan suatu ijtihad untuk mengarahkan konsep menuju Tuhan yang lebih terorganisir. Karena itu, kaum sufi diharuskan memiliki syaikh atau mursyid. Seperti dituturkan oleh Syaikh Yusuf:

... dalam bertarekat, kamu harus menyatukan syari'at dan hakikat, karena Nabi bersabda: "Aku diutus membawa syari'at dan hakikat". Nabi-nabi tidak diutus untuk membawa syari'at saja. Sabda Nabi yang lain: "Syari'at itu kata-kataku, tarekat itu hal-ku, dan hakikat itu hatiku. Seperti dikatakan bahwa Syaikh al-Imam abu Yazid al-Bustami mengatakan: "Tiap-tiap syari'at tanpa hakikat itu batil, dan semua hakikat tanpa syari'at itu kurang sempurna".

Syaikh Yusuf menekankan pentingnya pengetahuan dasar yang bersumber dari syari'at Islam. Pemahaman yang benar tentang syari'at akan membawa seseorang mencapai hakikat kebenaran. Seseorang akan mengetahui dan memahami ontologi hubungan antara Tuhan dan ciptaan-Nya berdasarkan epistemologi yang benar, yaitu syari'at.

Khan menyebutkan bahwa etika merupakan syarat yang ditekankan Syaikh Yusuf dalam rangka menuju kebenaran yang hakiki. Dan tarekat merupakan tahapan untuk menemukan apa yang benar dan apa yang salah. Berkenaan dengan etika di dalam tahapan tarekat, Syaikh Yusuf menganjurkan sikap-sikap sebagaimana yang dijelaskan oleh Jailani, yakni beberapa cara yang dianjurkan oleh guru-guru sufi: saling menasehati dalam kebenaran dan kesabaran, bersahabat dengan orang fakir, dan melayani waliyullah, ketergantungan seorang hamba kepada orang yang berada di atasnya adalah kesombongan, ketergantungannya kepada yang setara adalah akhlak yang buruk. Oleh karena itu, kefakiran dan tasawuf itu berat, sehingga disarankan untuk tidak mencampuradukkan sedikit pun di antara keduanya.

\section{Hakikat}

Menurut Syaikh Yusuf, hakikat adalah hati, batin atau gnosis (my heart). Hakikat mengacu pada makna terdalam dalam praktik dan bimbingan yang dibangun dalam syari'at dan tarekat. Hakikat adalah pengalaman langsung dalam kondisi mistis dalam sufisme dan pengalaman langsung dari kehadiran Tuhan dalam diri. Tanpa pengalaman ini, para murid hanya mengikuti secara buta, berusaha meniru orang yang telah mencapai tingkatan (maqam) hakikat.

Oleh karena itu, beberapa pernyataan di bawah ini sangat penting untuk diperhatikan:

a. Hati merupakan unsur utama dalam meraih hakikat, karena hati itu ibarat bejana.

b. Hati orang kafir adalah bejana terbalik yang tidak bisa dimasuki satu kebaikan pun.

c. Hati orang munafik adalah bejana pecah yang apabila dituangkan sesuatu dari atas akan merembes keluar dari bawah.

d. Hati orang beriman adalah bejana yang baik dan seimbang sehingga dapat menampung kebaikan yang dituangkan di atas hatinya. Hati kaum yang beriman bersih dari kelalaian dan 
kecerobohan sehingga bisa menjaga kesucian sesuatu yang dituangkan ke dalamnya. Hati kaum yang memiliki sedikit kotoran akan mencemari sesuatu yang dituangkan ke dalamnya. Hati kaum yang banyak memiliki kotoran akan mengotori semua kebaikan yang dituangkan ke dalamnya.

Jika hati kotor, tidak ada sedikit pun ruang untuk yang lain. Dengan demikian, penyucian hati berkaitan erat dengan usaha-usaha lahir dan batin yang dilakukan seseorang, misalnya berdoa dan berdzikir. Doa memiliki aspek lahir dan batin, yaitu doa yang diucapkan (lahir) dan keikhlasan (batin).

Syaikh Yusuf menjelaskan bahwa siapa pun yang telah mengetahui hakikat Tuhan, ia akan mencapai tingkatan yang lebih tinggi, yakni mengetahui hakikat kebenaran tentang Tuhan. Kebenaran yang tertanam di dalam hati dan diwujudkan dalam peribadatan sehari-hari, memberi gambaran bahwa orang di masa lalu memiliki gambaran filsafat sebagai mitos sebagaimana dilakukan di Yunani dengan cerita-cerita tentang dewa dewi, dan bahkan di pahatan-pahatan kayu dan batu. Kebenaran-kebenaran itu ditonjolkan dalam gambar-gambar yang diukir di tempat-tempat peribadatan. Gambar yang berfungsi sebagai simbol merupakan doa bagi pemeluk agama tersebut. Inilah yang membedakan Islam dari agama lain

\section{Makrifat}

Dalam al-Nafhat al-Sailaniyya, Syaikh Yusuf memaknai kata "makrifat" sebagai rahasia atau hakikat (gnosis). Makrifat adalah kearifan puncak atau pengetahuan tentang kebenaran spiritual. Makrifat adalah level yang paling dalam dan tinggi dari pengetahuan batin dan melampaui hakikat. Makrifat lebih dari sekadar pengalaman spiritual sesaat, dan makrifat merujuk pada kondisi-kondisi keselarasan dengan Tuhan dan kebenaran. Makrifat adalah pengetahuan tentang realitas yang dapat dicapai oleh hanya sedikit orang. Makrifat merupakan tingkatan para nabi, rasul, waliyullah, dan para bijak.

Tahapan makrifat memungkinkan seseorang yang telah sampai kepada-Nya, menyebut Tuhan dengan sepenuh hati. Seseorang akan menemukan cahaya Ilahiyah, yaitu jalan kebenaran dalam kehidupannya. Makrifat merupakan jalan

mengenali zat dan sifat-Nya secara benar, karena mengenal Allah merupakan suatu pengetahuan yang paling sulit. Hal ini karena tidak ada sesuatu pun yang menyamai eksistensi Allah. Allah memuji hamba yang mengenali-Nya. Sebaliknya, Dia mencela hamba yang tidak mengenali-Nya dan mengingkari-Nya. Ahli makrifat adalah orang yang mempunyai kemampuan untuk menyaksikan zat, sifat, dan perbuatan-Nya, sedangkan orang alim adalah orang yang dikaruniai pengetahuan melalui keyakinan, bukan dengan penyaksian. Pendapat lain menyebutkan bahwa makrifat adalah suatu keyakinan yang muncul setelah perjuangan ibadah. Menurut Imam al-Ghazali, Allah terlalu besar untuk dapat ditangkap oleh pancaindra, akal, dan analogi, bahkan keagungan-Nya terlampau besar untuk dapat dijangkau oleh selainNya.

Secara etimologis, makrifat adalah pengetahuan tanpa keraguan sedikit pun. Dalam terminologi kaum sufi, makrifat disebut pengetahuan yang tidak disertai keraguan di dalamnya ketika pengetahuan itu berkaitan dengan zat Allah dan sifat-sifat-Nya.

Upaya yang dapat dilakukan untuk menimbulkan rasa takut kepada Allah terkait makrifat adalah hati yang tenang, yaitu dengan mengingat Allah, baik secara terang-terangan atau 
sembunyi-sembunyi. Hal ini akan terjadi jika seseorang sudah merasa yakin bahwa Allah mampu melihat segala gerak-gerik dan keyakinan bahwa tidak ada sesuatu pun yang akan luput dari pengawasan-Nya, baik lahir maupun batin. Jika seseorang mampu memuliakan keadaan ini dan melaksanakannya dalam segala gerak-geriknya baik lahir maupun batin, maka ia akan terus-menerus khawatir karena merasa selalu diawasi oleh Allah. Seseorang yang selalu merasa diawasi Allah akan menjaga perilakunya karena khawatir melakukan sesuatu yang tidak diridhai-Nya.

Pemahaman tentang syari'at, tarekat, hakikat, dan makrifat yang diuraikan Syaikh Yusuf dalam karya-karyanya, merupakan ciri dan corak etika Syaikh Yusuf. Etika ini merujuk pada karyakarya sufi terdahulu, dengan berlandaskan Al-Qur-an dan sunnah serta pandangan ulamaulama sufi yang hakiki terdahulu, yaitu ulama-ulama yang memahami syari'at lahir dan batin serta mengamalkannya dalam kehidupan sehari-hari.

Akhirnya, konsep-konsep kunci etika sufisme Syaikh Yusuf, seperti yang diuraikan di atas, merupakan inti dari dakwah Islam dari masa ke masa. Oleh karena itu, siapa pun yang melakukan dakwah Islam seharusnya memiliki pandangan yang mendalam dan luas mengenai konsep-konsep tersebut di atas. Pandangan yang mendalam tersebut tentunya didasarkan pada sumber-sumber literatur Islam. Dengan demikian diharapkan dakwah yang dijalani merupakan cerminan dari pesan inti Islam, yaitu menjadi rahmat bagi semesta alam.

\section{$\mathrm{BAB} 4$}

\section{UNIVERSALISME PESAN ETIS}

\section{DALAM KARYA SYAIKH YUSUF}

\section{A. Pesan Ilahi dalam Teks Keagamaan dan Universalisme}

Islam dalam Karya-karya Syaikh Yusuf Ajaran pokok tarekat Syaikh Yusuf, berkisar pada usaha manusia untuk mendekatkan diri kepada Allah Swt., mengacu pada peningkatan kualitas akhlak yang mulia serta penekanan amal saleh dan dzikir. Ibadah shalat dan dzikir merupakan amalan yang dapat membawa salik (hamba) sampai ke ujung suluknya. Kedudukan dzikir dalam tarekat Syaikh Yusuf menempati posisi yang sangat penting. Ini adalah salah satu amalan untuk mencapai kebahagiaan sempurna bagi seorang hamba untuk dapat mencapai Tuhannya.

Seperti halnya sufi-sufi lain, Syaikh Yusuf mengatakan bahwa tujuan utama dari perjalanan hamba dalam suluknya adalah untuk bertemu dengan Tuhan. Ada tiga jalan yang biasa ditempuh untuk sampai kepada Tuhan, yaitu: pertama, jalan orang kebanyakan, yaitu dengan memperbanyak amal-amal lahir seperti shalat, puasa, haji, zakat, jihad, dan lain lain. Kedua, jalan ahlu al-mujahadah, yaitu jalan orang-orang yang lebih mementingkan amalan-amalan batin melalui latihan-latihan keras, misalnya menghilangkan akhlak buruk dan menggantinya dengan akhlak baik, membersihkan jiwa, menyucikan hati, mengosongkan roh, dan lain-lain. Ketiga, jalan ahlu az-dzikr dan ahlu al-muhabbah kepada Allah secara dzahir dan batin. Kelompok ini menyejajarkan amalan dzahir dan amalan batin

Jiwa seseorang akan menjadi mulia dengan berperilaku baik kepada Tuhan dan manusia. Jiwa yang mulia adalah jiwa yang terjaga dari kehinaan, kerendahan, dan ketamakan. Berbeda 
halnya dengan kesombongan yang timbul dari kebanggaan atas diri dan penghinaan terhadap orang lain, dua anggapan ini yang kemudian memicu timbulnya kesombongan. Sementara sikap baik dan jiwa mulia lahir dari budi pekerti yang mulia, yaitu kemuliaan jiwa dan penghormatan atau pengagungan terhadap Tuhan.

Selanjutnya, pembahasan tentang pesan universal Islam, perlu memahami isi kandungan teks yang seringkali bercampur antara akhlak dan ajaran-ajaran fiqh serta tasawuf. Memilih ajaran yang universal dari teks naskah Syaikh Yusuf, seringkali ditemukan di satu paragraf atau dari suatu naskah merupakan intisari dari pesan-pesan universalnya. Dapat dikatakan bahwa hampir seluruh tulisan Syaikh Yusuf menekankan pentingnya pelaksanaan syari'at dalam pengertian yang luas dan juga pelaksanaan fiqh dan tasawuf. Fiqh dan tasawuf dalam pengertian universal merupakan aspek lahir dan batin dari setiap agama. Fiqh mewakili aspek lahiriah dari ketentuan-ketentuan ajaran agama, dan tasawuf mewakili aspek batin. Setiap agama memiliki kedua aspek ini, meskipun menggunakan istilah yang berbeda. Inilah yang dimaksud dengan aspek universal yang sering diungkapkan secara berulang-ulang oleh Syaikh Yusuf.

Teks terpenting dari karya Syaikh Yusuf yang mengandung ajaran-ajaran universal adalah Bidayat al-Mubtadi, yang menerangkan tentang Tuhan Yang Maha Satu atau Tunggal, yang berkuasa atas segala sesuatu. Bagian penting dari naskah tersebut dapat dilihat sebagai berikut: Adapun pengetahuan mengenai Allah Ta'ala itu, supaya hamba mengetahui bahwa Allah Ta'ala mempunyai sifat-sifat yang sempurna, Tuhan itu pencipta semesta alam, semua yang maujud, zatnya, sifatnya pekerjaannya yang baik dan buruk, semua di bawah kekuasaan-Nya dan kehendak-Nya. Adapun mengenai kepercayaan kepada Hak Ta'ala adalah sebagai berikut: Sesungguhnya Tuhan itu Laysa kamitslihi Syai'un". Allah itu satu, tak ada teman dalam zatNya, sifat- Nya, dan af'alNya (perbuatan-Nya). Tuhan berbeda dengan semua yang dikhayalkan dalam pikiran manusia.

Syaikh Yusuf menekankan pentingnya etika yang baik tidak hanya kepada Tuhan, tetapi kepada seluruh makhluk tanpa memandang suku, agama, ras atau golongan. Bahkan seseorang yang sedang menuju Tuhan sekalipun, diharuskan memiliki etika yang luhur dan mulia. Siapa pun yang belum memiliki etika religius, tidak akan sampai pada derajat mengenal Tuhan, atau ia tidak dapat menjadi orang yang benar-benar saleh.

\section{B. Etika Religius Syaikh Yusuf dalam Dakwah}

Konsep al-takhalluq bi akhlaq Allah (berakhlak dengan akhlak Allah) mengandung arti bahwa seseorang harus berusaha mencontoh dan mempraktikkan sifat-sifat Tuhan (al-asma al-husna), kecuali sifat kibr (kesombongan). Melalui jalan ini seseorang akan mencapai kesucian moral lahir dan batin. Hal ini penting dalam melaksanakan dakwah Islam, karena dari basis nilai seperti inilah metode dakwah Syaikh Yusuf diterima dan berkembang. Metode dakwah Syaikh Yusuf sangat adaptif dalam mengembangkan ajaran-ajaran Islam sesuai dengan kondisi objektif Indonesia yang plural, dan hal ini diperkuat oleh penguasaan Syaikh Yusuf terhadap aspek-aspek Islam, baik secara lahir maupun batin. Pemahaman Syaikh Yusuf yang komprehensif ini membuat dakwahnya jauh dari unsur-unsur pemaksaan akan doktrin agama.

Corak etika Syaikh Yusuf juga berbeda dengan pola-pola dakwah yang dikembangkan sekarang ini. Etika dakwah Syaikh Yusuf berlangsung secara rasional, estetis, dan etis sehingga mudah diterima oleh masyarakat. Hal ini tidak hanya ditopang oleh keselarasan pandangannya tentang manusia sebagai hamba Tuhan, tetapi juga karena adanya kesejajaran intensitas amal 
danperilakunya secara lahir dan batin, atau sebagai corak dasar dakwah yang sufistik. Oleh karena itu, metode dan substansi dakwah Syaikh Yusuf perlu diapresiasi dalam konteks Indonesia sekarang ini, karena coraknya yang mengayomi, menyejukkan, dan mencerahkan serta jauh dari tindakan anarkis dan teror, sehingga Islam sebagai rahmatan lil alamin dapat diwujudkan.

\section{BAB 5}

\section{REFLEKSI TEORETIS ETIKA RELIGIUS}

\section{SYAIKH YUSUF}

\section{A. Refleksi dalam Konteks Keindonesiaan}

Terkait dengan krisis kemanusiaan yang terjadi di Indonesia dewasa ini, ada dua teori yang perlu ditempatkan, yaitu: humanisme dan radikalisme. Kedua teori ini akan diangkat dalam dua kenyataan yaitu humanisme yang diajarkan oleh Syaikh Yusuf yang masih relevan untuk diaktualisasikan, dan radikalisme agama yang digerakkan oleh organisasi-organisasi seperti Front Pembela Islam (FPI) yang muncul di Indonesia.

Humanisme yang dikembangkan oleh kaum sufi seperti Syaikh Yusuf sangat kontras dengan humanisme model Barat, yang tidak memiliki muatan moral dan wawasan spiritual karena ia muncul dari ontologi dan epistemologi yang mengagungkan manusia, yang menjadikan manusia sebagai pusat dan ukurannya. Humanisme Barat, kosong dan semu karena lebih mementingkan peradaban pikir (Iptek) dan materi yang pada akhirnya berujung pada dehumanisasi, demoralisasi, dan despiritualisasi.

Inti dakwah Syaikh Yusuf, adalah kebaikan moral dan etika luhur pada sesama manusia, bahkan pada sesama makhluk Tuhan. Dalam hal ini ajaran-ajaran etikanya yang berlandaskan ajaran Islam mengandung pesan-pesan moral dan spiritual yang dapat digali serta dikembangkan, terkait dengan filsafat dakwah bagi masyarakat Indonesia yang majemuk. Hal ini penting untuk ditekankan, karena sebagai putra daerah, atau ulama yang lahir di bumi Nusantara, Syaikh Yusuf telah membuktikan bahwa selain memahami ajaran-ajaran Islam 
dengan baik secara lahiriah atau fiqh dan secara batin, Syaikh Yusuf juga memahami sejarah dan kebudayaan bangsanya.

\section{B. Etika Religius Syaikh Yusuf dalam Dakwa}

moral yang mulia atau moralitas religius dalam ajaran Syaikh Yusuf dapat diungkapkan sebagai berikut:

1) Sebagai etika yang tinggi dan menjadi kata kunci dalam pelaksanaan kewajiban dan tugas dalam kehidupan sehari-hari, baik dalam hubungan antarmanusia maupun antara manusia, alam, dan Tuhan.

2) Moralitas religius adalah kualitas dalam perbuatan manusia yang menunjukkan bahwa perbuatan itu benar atau salah, baik atau buruk. Moralitas mencakup pengertian tentang estetisnya perbuatan manusia.

Berkaitan dengan inilah maka ajaran agama yang menekankan tentang etika menjadi pembahasan yang berkaitan erat, dan Tuhan adalah sumber dan norma dari segala sesuatu yang ada. Selain itu, Tuhan juga merupakan sumber dan norma segala kebaikan. Sebab terakhir mengapa suatu perbuatan manusia itu baik adalah karena mengambil bagian dalam kebaikan Tuhan.

Berkaitan dengan pandangan etika religius Syaikh Yusuf, yang menekankan pentingnya etika individu dalam kaitannya dengan kehidupan bermasyarakat dan sosial serta tanggung jawab setelah kehidupan ini, yaitu kehidupan masa depan di alam yang berbeda yaitu alam akhirat, maka tanggung jawab, bagi etika religius Syaikh Yusuf yang berdasarkan keislaman kepada Tuhan sang pencipta, memiliki dimensi universal kemanusiaan sekaligus dimensi primordial antara manusia dan Tuhan.

Dua hal yang dalam Islam disebut hablum minallah dan hablum minannas atau hubungan dengan Tuhan dan manusia inilah yang menjadi landasan etika religius yang dikembangkan oleh Syaikh Yusuf. Menurut pandangan Syaikh Yusuf, yang tentu saja bersumber dari Islam, kedua hal tersebut harus seimbang. Apabila salah satu ditinggalkan, maka tidaklah sempurna.

Setidaknya, secara keseluruhan ada lima kunci dari karya-karya Syaikh Yusuf yang sangat penting untuk dicermati, yaitu pentingnya tauhid, syari'at Islam, tarekat, makrifat, atau filsafat tentang Ketuhanan dan hakikat atau wahdat al-wujud atau filsafat tentang kesatuan eksistensi. Artinya alam ini adalah cerminan dari eksistensi Tuhan.

\section{BAB 6}

\section{PENUTUP}

Syaikh Yusuf dikenal sebagai figur dai, ahli tarekat, sekaligus ulama syari'at yang andal. Sebagai sufi besar, ia menguasai dan mengamalkan ajaran Islam secara menyeluruh dan telah mencapai puncak pendakian spiritual tertinggi dalam suluknya, sehingga menjadi wali yang suci dan karomah, bahkan ia berperan juga dalam persoalan sosial dan politik. Ia menjadi tokoh ulama di Kerajaan Islam Makassar, mufti di Kerajaan Islam Banten, juga pejuang yang memiliki patriotisme besar melawan kedzaliman penjajah di Nusantara, bahkan menjadi tokoh yang berpengaruh di berbagai negara. Syaikh Yusuf adalah salah satu mujadid terpenting dalam sejarah Islam di Indonesia. Jejaknya meliputi wilayah yang sangat luas, dari Sulawesi Selatan dan Jawa Barat, sampai ke Arabia, Sri Lanka, dan Afrika Selatan. 
Teori-teori etika religius yang dikembangkan Syaikh Yusuf bersumber dari Al-Qur'an, tentang manusia dan kedudukannya di alam semesta. Etikanya didasari pada pandangan dunia AlQur'an, sunnah, konsep-konsep teologi, kategori-kategori filsafat, dan sufisme.

Corak dakwah Syaikh Yusuf yang tidak hitam-putih, langsung menyentuh aspek syari'at yang paling dalam (batin manusia), dan kemudian melaksanakan ajaran-ajaran syari'at dengan etika lahir-batin yang sangat dibutuhkan. Dengan pendekatan sufistik, Syaikh Yusuf mendapat simpati dari pelbagai lapisan masyarakat, raja, punggawa, dan rakyat jelata. Keberhasilan ini tidak hanya terjadi di Nusantara, namun juga di mancanegara, tempat Syaikh Yusuf pernah menyebarkan ajaran dan dakwahnya.

Etika religius Islam yang dikembangkan oleh Syaikh Yusuf merupakan ajaran-ajaran luhur ketuhanan yang sesuai dengan pandangan-pandangan universal pemikir-pemikir non-muslim lainnya yang juga menaruh perhatian besar pada etika religius. Persamaan dari seluruh pemikir etika religius walaupun berbeda agama adalah bahwa etika hidup yang dikembangkan dalam masyarakat memiliki tanggung jawab kepada sesama individu dalam masyarakat sekaligus tanggung tawab kepada Tuhan.

Penekanan dalam etika religius adalah pada pandangan dunia yang komprehensif, yaitu dunia kini yang ditempati dan dunia yang akan datang. Pemahaman komprehensif inilah yang sebenarnya dirindukan oleh masyarakat modern yang tampaknya mulai haus akan unsur-unsur spiritual. 